\title{
The Implementation Tandur Quantum Teaching Learning Model to Improve Social Learning Achievement
}

\author{
Maha Lastasa $^{1}$ Buju Basafpipana Habaridota ${ }^{2}$ \\ ${ }^{12}$ Program studi pendidikan guru madrasah ibtidaiyah, fakultas tarbiyah dan ilmu keguruan IAIN Pontianak, Indonesia
}

\author{
A R T I CLEINFO \\ Article history: \\ Received 18 March 2020 \\ Received in revised form \\ 30 April 2020 \\ Accepted 5 May 2020 \\ Available online 15 May \\ 2020 \\ kata kunci: \\ quantum teaching, tandur, \\ prestasi belajar
}

Keywords:

Quantum Teaching,

TANDUR

Study Achievement

\begin{abstract}
A B S T R A K
Permasalahan penelitian ini yaitu: a) anak kurang dapat mengembangkan nilai dan sikap dalam kehidupan sehari-hari; b) pengajaran IPS dilaksanakan dalam waktu yang terbatas, sehingga tidak mungkin dapat memperkenalkan seluruh nilai-nilai kehidupan manusia kepada anak. Maka dari itu proses pembelajaran seyogyanya menekankan pada proses pembelajaran yang menyenangkan dan sesuai dengan kemampuan beserta gaya belajar anak. Oleh sebab itu tujuan dari penelitian ini adalah menganalisis dampak pengaruh model Quantum Teaching teknik TANDUR terhadap prestasi belajar IPS SD. Jenis penelitian ini pola dasar The Posttest Only Control Group dengan jenis eksperimen semu (eksperimen quasi). Populasi penelitian berjumlah 106 anak dan sampel penelitian berjumlah 70 anak. Data dianalisis dengan menggunakan MANOVA (multivariat Analysis of Variance) berbantuan SPSS 17.00 for windows. Hasil penelitian menunjukkan prestasi belajar IPS antara anak yang mengikuti model pembelajaran Quantum Teaching teknik TANDUR secara signifikan lebih baik daripada anak yang mengikuti model pembelajaran konvensional ( $\mathrm{F}$ sebesar 13.682 dan sig $=0,000 ; \mathrm{p}<0,05$ ), Sehingga terdapat perbedaan preastasi belajar anak yang belajar menggunakan model Quantum teaching teknik TANDUR dan belajar secara konvensional. Dengan adanya penelitian ini akan memberikan gambaran bagi guru untuk berinovasi dengan menerapkan berbagai model pembelajaran untuk menciptakan pembelajaran
\end{abstract} yang bermakna dan akan berdampak pada prestasi belajar anak yang semakin meningkat.

\section{A B S T R A C T}

Social studies is a subject with memorizing learning that scared some students of it is applied without considering students need and students' various learning style. Indirectly this situation would affect the students' learning outcomes. Besides, there are some difficulties happen in social studies for advance class, such as: a) Students have low ability on developing traits and attitude in daily life; b) IPS only taught in a very limited time. So, it is hard to cover all the important values. Therefore, learning process should emphasize on an enjoyable process that relates to ability and Students learning style. The purpose of this research is to analyze the impact of the Quantum Teaching Technique TANDUR towards social studies for elementary school students' learning achievement. The type of research is the basic pattern of The Posttest Only Control Group with a quasi-experiment. The research Will conduct on the sixth grade of Elementary School Students in SD 07 Sungai Raya Kubu Raya Regency, Kalimantan Barat. The population of the research consists of 106 Students, with 70 Students as the sample. Data analysis used in this research is MANOVA (Multivariant Analysis of Variance) assisted by SPSS 17.00 by windows. The result shows that IPS learning achievement between Students with Quantum Teaching Technique TANDUR learning model is more significant than Students with a conventional model ( $F 13.682$ and sig $=0,000 ; p<0,05$ ). This research would give an overview of teacher's innovation by applying various teaching models to create meaningful learning to improve Students learning achievement.

\section{Introduction}

The success of the learning process can be seen from the learning achievements they gained. Learning achievement is the result of learning that is achieved after going through the process of teaching and learning (Shafi'i, 2018). Achievement and learning is a unity that correlates to each other. Learning is a process of behavioral change from various activities to achieve achievement, while achievement is a manifestation of the outcome of the learning process. Learning process should be

Copyright (C) Universitas Pendidikan Ganesha. All rights reserved.

${ }^{1}$ Corresponding author.

E-mail addresses: mahalas01@gmail.com¹(Maha), habaridota999@gmail.com²(Buju) 
designed systematically focused on child's attention, (Al Farizi, M. F., Sudiyanto, 2019; Zakirman, 2017). Learning development takes teamwork between teachers and children to achieve the desired learning objectives, (Gentry, 2013). The achievement of learning objectives can be seen from child's achievement.

Learning achievement is very important in school. This is supported by the role of a teacher. The ability of a teacher to design and implement the learning process will have an impact on improving student achievement (Lott, J., \& Kenny, 2013) in the form of scores and in accordance with test standards for results that are on target (Geel, 2015). Likewise, social studies learning, an educational program that contains a lot of value content as one of its characteristics, this is as stated by (Gunawan, 2012), that: Social Sciences (IPS) and Humanities are two potential fields of study for the development of tasks learning tasks that have many values, scientific characteristics that are closely related to human life and a lot to discuss about how humans can establish harmonious relationships with others, the environment and God, which makes these two studies very rich in attitudes, values, morals, ethics and behavior.

In social studies learning for high classes, there are some difficulties experienced by children, such as: a) children are less able to develop values and attitudes in daily life; b) social studies teaching is carried out in a limited time, so it is not possible to introduce all the values of human life to children. This is reinforced as published by (Depdiknas, 2007) reveals, that: children often feel bored, boredom can arise in addition to the result of lack of understanding what exactly social studies, learning methodology used often does not succeed in attracting the attention of children, even educators often do not have a clear reference, especially creativity to create interesting methods to use in teaching boredom can also arise due to subject matter not following the level of development and context of children's lives. This happens because the characteristics of students differ in each of these schools.

This is in line with findings in the field, which relate to the learning process of social studies. Where identified educators who are still struggling with old patterns of teaching (conventional) and less responsive even do not want to know about learning innovation, educators who are less skilled in creating pleasant and meaningful learning conditions, children lose their enthusiasm for learning because they find learning unattractive and difficult, underutilized infrastructure, children are accustomed to teaching patterns of educators who do not stimulate thinking skills so that children tend to be lazy and lack initiative in learning, lack of collaboration between school and community, presentation of material by educators less attractive to children, lack of positive emotional relations between teachers and children like feeling comfortable, open, happy and so forth.

These findings have an impact on children's learning outcomes are relatively low. The low learning outcomes of sixth grade of IPS class SDN 07 Sungai Raya, can be seen from the acquisition of final school exam scores. Data on the results of examinations (NEM) of children in the last three years, namely: a) In 2009-2010 data from 99 children who took the final exam, 54 children received grades below 7.00 with the highest score of 9.00 and lowest score 6.00; b) in 2010-2011 out of 97 children who took UAS, 79 children scored below 7.00 with the highest score of 8.32 and the lowest 5.27; and c) in 2011-2012 out of 93 children who took the UAS, 54 children who scored below 7.00 with the highest acquisition of 9.80 and the lowest 4.50 .

Based on these data, in learning, especially social studies subjects, it is deemed necessary to innovate in the learning process, innovative learning based on constructivism learning approaches emphasizes the formation of active and accommodative understanding based on prior knowledge and meaningful learning experiences (Sarwi, 2013), especially in the use of learning strategies and models that have been suspected as a factor causing the low learning outcomes of children. However, it does not rule out the existence of other factors, as stated by (Djaali, 2012) there are four influential factors, namely: students, schools, families and communities. This if left unchecked will have a bad impact on the learning process of students which can lead to low student achievement and not develop.

(Jaynes, 2016) states that, "For teachers who want to actively create models and increase learning desires, there is one word that can be included, namely enthusiasm. This is reinforced by the findings of Lozanov's research in (De Porter, 2017) showing that "the influence of educators is very clear on children's success". Teachers and students are very dominant determinants in general education because teachers and students play a role in the learning process, where the learning process is the core of the overall education process aimed at changing the behavior of children (Kirom, 2017). This process is the notion of Ki Hajar Dewantara's thoughts based on education summarized in the motto: ing ngarso sung tulodo (educators are in front of role models); in madyo mangun karso (educators are always in the middle and continuously initiating/motivating), and tut wuri handayani (educators always support and encourage students to move forward) have become very popular 
expressions to this day. His commitment and dedication to developing the cultural identity of the nation's children through education to realize an independent state cannot be denied (Musyafa, 2015).

A good learning process certainly takes into account the characteristics of children, especially elementary school, children aged 7-11 are at the stage of concrete operations characterized by the development of systems of thought that are based on certain logical rules (logical operations) and the operation is reversible meaning can be understood in two directions, the ability to sort and classify objects ". The teacher needs to know each student and the special talents they have to be able to provide the educational experience needed by each student to be able to develop their talents optimally following the educational goals (Abdullah, 2017). These characteristics provide a platform for educators to treat children according to their stages of cognitive and psychological development. The child at this stage views the world in its entirety as a whole, and regards the coming year as a time away. What they care about is the present (concrete) and not the future that they do not yet understand (abstract). That is why elementary social studies learning moves from the concrete to the abstract by following a pattern of increasingly widespread environmental approaches and a spiral approach (starting from easy to difficult).

Expected learning is not only oriented towards cognitive abilities, but also oriented to how students can learn from the environment, experience, greatness of others, from the richness and extent of the expanse of nature, so they can develop creative attitudes and imaginative thinking power. As well as remembering the reformation in the body of knowledge and communication technology, students should be trained on how they should deal with the various problems that students will face both in their homes, schools and communities in this globalization era. Another important social skill is decision making, which is a very important component in the lives of every individual, including in an organization. Decision making can also affect a person's success or failure in his life (Sola, 2018). All of these need to be trained so that children get used to and mentally honed when they grow up.

To that end, in social studies learning educators are obliged to train children to make decisions while creating an educational atmosphere that is meaningful, fun, creative, dynamic and dialogic, has a professional commitment to improve the quality of education, as well as set an example, maintain the good name of the institution, and the profession following the trust given to him. The intended learning is to condition the environment (context) and the content (learning content) in such a way as to foster a positive aura on each side of the class. The process of constructing knowledge prioritizes direct experience so that the goal of constructivist learning is to create new insights that require productive creative activities in real contexts that encourage the learner to think and rethink and demonstrate (Riyanto, 2012). Realizing it without ignoring different aspects of children's abilities.

Preparation in terms of context which includes: a dynamic learning design, an empowering atmosphere, a solid foundation and a supportive environment as well as content in this case in the form of excellent presentation, flexible facilities, learning skills for learning and life skills (De Porter, 2017). Both of these, if properly realized will produce unexpected quantum. Because an effective learning process is to create learning that is loaded with meaning and fun. Meaningful learning is fun learning that will have an advantage in capturing all the information intact so that the final consequences increase the ability of children (Najib, 2016). Meaningful learning is a process of relating new information to relevant concepts contained in a person's cognitive structure. Thus, for meaningful learning to occur, the teacher must always try to find out and explore the concepts students have and help them harmoniously integrate these concepts with new knowledge to be taught.

Based on these problems, the learning model that is thought to influence social studies achievement is the Quantum Teaching learning model TANDUR technique (Astiti, 2017) reveals that Quantum Teaching is changing various interactions that exist in and around the moment of learning. (Lestari, 2018) states that the Quantum teaching model helps the learning process to take place royally to arouse students' interest in learning. (Adoe, 2016) who found that there was a positive influence on the activeness and learning outcomes of social studies after applying the quantum teaching learning model.

The objectives to be achieved in this research are to find out the significant influence of the TANDUR technique Quantum Teaching learning model on social studies learning achievement. This model provides a great opportunity to develop all the potential that exists in children, this model outlines new ways that facilitate the learning process through scouting elements of art and directed achievements whatever the subject, this model at the same time invites educators to educate in the right way, fun, and impressive. 


\section{Method}

This type of research carried out was a quasi-experimental, with the basic pattern of "The Posttest-Only Control-Group Design". This study measures two variables, namely the independent variable of the TANDUR technique Quantum teaching model while the dependent variable is elementary school social studies learning achievement. The sampling technique used was random sampling with a total of 70 children sampled to determine the class to be used as the control and experiment class. The data collection instrument used in this study was a multiple choice test that would be given at the end of the study (posttest). The test used is a multiple choice test with one correct answer. The test is compiled based on the questionnaire questions that have been made following Basic Competencies and indicators. After the lattice is made, before it is used to measure the results of social studies learning, a lattice in the form of an instrument will be tested and analyzed to determine the validity, reliability, difficulty level and different power of the items. The research data were analyzed in stages, namely: data description, prerequisite tests, and hypothesis testing. The prerequisite tests conducted were the test for normality of data distribution, homogeneity of variance tests, and tests between dependent variables. After the prerequisite tests that have been done meet the requirements, then the statistical analysis used to test the hypothesis is using MANOVA. Data analysis was performed which consisted of two tests namely prerequisite test and hypothesis test. The prerequisite tests conducted are the normality test and the homogeneity test, where both of these tests aim to find out whether the research results are normal and homogeneous, which will later be used for the terms of the hypothesis test. To test the hypothesis used paired sample t-test with the provisions of 1) reject Ho if the sig. (2-tailed) is smaller than the alpha (0.05), and 2) accept Ho if the sig. (2-tailed) is greater than the alpha $(0.05)$.

\section{Result and Discussion}

This research is a quasi-experimental study, by looking for the effect of using the TANDUR technique quantum teaching model on social studies learning achievement in elementary school. Aspect of learning achievement measured 8 indicators with multiple choice questions. Data analysis in the study used MANOVA (multivariate Analysis of Variance) assisted by SPSS 17.00 for windows by previously conducting prerequisite tests namely normality and homogeneity tests. The normality test uses the Kolmogorov-Smirnov test and for testing the homogeneity of the data using the Levene test. Calculation results for normality and homogeneity data tests can be seen in Table 1.

Table 1. Rekapitulasi Hasil Pengujian Normalitas Sebaran Data dengan Uji Kolmogorov-Smirnov dan Shapiro-Wilk dengan Taraf Signifikansi $5 \%$

\begin{tabular}{|c|c|c|c|c|c|c|c|}
\hline \multirow{2}{*}{$\begin{array}{c}\text { Variabel/Learning } \\
\text { Model }\end{array}$} & \multicolumn{3}{|c|}{ Kolmogorov-Smirnov } & \multicolumn{3}{|c|}{ Shapiro-Wilk } & \multirow[t]{2}{*}{ Conclusion } \\
\hline & Statistic & Df & Sig & Statistic & Df & Sig & \\
\hline $\begin{array}{l}\text { Social Studies Learning } \\
\text { Achievement of children }\end{array}$ & 0,145 & 35 & 0,060 & 0,954 & 35 & 0,155 & Berdistribusi \\
\hline who follow the & & & & & & & \\
\hline TANDUR technique & & & & & & & \\
\hline $\begin{array}{l}\text { Quantum } \\
\text { model }\end{array}$ & & & & & & & \\
\hline $\begin{array}{l}\text { Prestasi Belajar IPS anak } \\
\text { yang mengikuti model } \\
\text { pembelajaran } \\
\text { konvensional }\end{array}$ & 0,072 & 35 & 0,200 & 0,986 & 35 & 0,932 & $\begin{array}{c}\text { Berdistribusi } \\
\text { normal }\end{array}$ \\
\hline
\end{tabular}

Tampak bahwa statistik Kolmogorov-Smirnov memiliki angka signifikansi lebih besar dari 0,05. Maka semua sebaran menurut model pembelajaran berdistribusi normal.

Tabel 3. Hasil Analisis Uji Levene's Test

\begin{tabular}{lcccrr}
\hline & F & df1 & df2 & Sig. \\
\hline IPS Learning achievement & 0,635 & 1 & 68 & & 0,428 \\
\hline
\end{tabular}


Based on the homogeneity test together using the Box'M test produced a significant number of 0.430 and individually with the Leven's test resulted in a significant number of 0.428 for the social studies learning variable. It can be concluded that the data group of elementary school social studies learning achievement evaluation between before and after the use of the Quantum teaching model TANDUR technique in social studies as if the elementary school has been homogeneous.

Table 4. Hypothesis Test for Social Studies Learning Achievement

\begin{tabular}{clccccc}
\hline Source & \multicolumn{1}{c}{ Dependent Variabel } & Df & RJK & F & Sig. \\
\hline Learning Model & $\begin{array}{l}\text { Children's } \\
\text { Learning } \\
\text { Achievement }\end{array}$ & Social & 1 & 1760,014 & 13,682 & 0,000 \\
\hline
\end{tabular}

The results of data analysis of social studies learning achievements of children who follow TANDUR Quantum Teaching techniques with conventional learning F score was 13,682, $\mathrm{df}=1$, and $\operatorname{sig}=0,000$. This means that the significance is less than 0.05 . Thus, the null hypothesis (H0) is rejected and the alternative hypothesis $(\mathrm{Ha})$ which states there are differences in social studies learning achievement between children who take learning the TANDUR technique Quantum Teaching model and children who follow conventional learning models, is accepted.

Based on the data from the research, the quantum teaching model of tandur technique has a positive impact on learning achievement. This is inseparable from the advantages of the TANDUR type quantum teaching model. Quantum Teaching also includes all the connections, interactions, and differences that maximize the learning moment, (Cahyaningrum, Amaliyah Dwi, 2019). (Astiti, 2017) revealed Quantum Teaching is changing various kinds of interactions that exist in and around the learning moment. When viewed from the learning syntax of growing, natural, naming, demonstrating, repeating and celebrating (TANDUR) this model has the advantage of being able to be used in all subjects through scouting elements of art in it, besides that this model combines learning features towards the form of learning planning that will boost children's achievement. With a good interaction between children and all the musty learning will be able to increase student achievement.

Good learning achievement, of course, cannot be separated from the learning process carried out, it is necessary to have appropriate learning strategies and innovations to maximize the potential of children. The innovation that must be done is by paying attention to the characteristics of children, especially elementary school children, choosing a model that is following the character of the subject matter and following the standards of the educational process that seeks to instill character education to children. Because essentially the learning objectives are in principle the same, namely changes in behavior, only different ways or efforts to achieve them (Hamalik, 2012) in line with Cronbach (Sardiman, 2017)which states "Learning is shown by a change in behavior as a result of experience ".

One of the intended learning models of innovation is the TANDUR Quantum Teaching learning model. Quantum Teaching according to (De Porter, 2017)) is a lively change of learning, with all the nuances that include all the connections, interactions, and differences that maximize the learning moment. Learning developed with the TANDUR Quantum Teaching technique is more likely to occur in the process of constructing knowledge. The learning process will be more meaningful if the child constructs his knowledge and experiences directly from what he has learned, (Mulyati, 2016). In this process, the child usually has discussions with peers or groups to express ideas so that the thinking process is following the experience of each child can be well accommodated. The application of the TANDUR Quantum Teaching learning model can be used at every level of education from elementary school to college.

Based on what has been stated, educators are expected to innovate learning models where more active children (student center) to construct knowledge following the potential of each child. The TANDUR Quantum Teaching learning model provides freedom for children to explore and elaborate on their knowledge and can confirm the new knowledge they have acquired where children are invited to learn in a fun yet focused way. This model requires educators to be more patient in directing children to new things, given that children are accustomed to teaching patterns that are ready to serve but pay less attention to children's needs and the creativity of educators will be honed by utilizing various learning resources and keep in mind that a process does feel heavy at the beginning but will be easy in the end.

The results of this study are strengthened by research conducted by (Adoe, 2016)in his research finding a positive influence on the quantum teaching learning model. In line with this (Cahyaningrum et al., 2019) in his research also found a positive influence on student learning outcomes after applying the TANDUR type quantum teaching learning model. (Khairani, Annisa Laras, 2016) in his research found an increase in learning outcomes after applying the TANDUR type quantum teaching model. 


\section{Conclusion}

The purpose of this study was to look at the effect of the use of the TANDUR Quantum Teaching model on social studies learning achievement in elementary schools. Based on the results of data analysis, it can be concluded that there are significant differences in elementary social studies learning achievement between children who learn by using TANDUR Quantum Teaching technique and conventional learning. Social studies learning using the TANDUR Quantum Teaching technique model is prove to be able to involve all active children in learning because the models are developed according to the learning needs of children at the elementary level. This model can also increase selfconfidence and cooperation, respect, respect and support friends for success and enthusiasm in learning many things. In the future, it is hoped that this model can not only be developed in social studies material, but can be extended to PPKn, natural science, mathematics and language materials at all grade levels in both elementary and higher education.

\section{References}

Abdullah. (2017). Pendekatan dan Model Pembelajaran yang Mengaktifkan Siswa. Edureligia /, 01(01), 45-62.

Adoe, D. P. (2016). Implementasi Pembelajaran Quantum Teaching Untuk Meningkatkan Keaktifan Dan Hasil Belajar Ips Siswa Kelas V sd. . . E-Journal PGSD Universitas Pendidikan Ganesha Jurusan $P G S D, 4(1)$.

Al Farizi, M. F., Sudiyanto, \& H. (2019). Analysis of Indonesian language learning obstacles in primary schools. International Journal of Educational Methodology, 5(4), 663-669. https://doi.org/https://doi.org/10.12973/ijem.5.4.663.

Astiti, D. (2017). Penerapan Model Pembelajaran Contextual Teaching And Learning, Quantum Teaching Terhadap Motivasi Berprestasi Dan Hasil Belajar IPS Siswa Kelas VII. Jurnal Pendidikan IPS Indonesia, 1(2).

Cahyaningrum, Amaliyah Dwi, D. (2019). Pengaruh Model Pembelajaran Quantum Teaching Tipe Tandur Terhadap Hasil Belajar. Indonesian Journal of Science and Mathematics Education, 2(3).

Cahyaningrum, A. D., AD, Y., \& Asyhari, A. (2019). Pengaruh Model Pembelajaran Quantum Teaching Tipe Tandur Terhadap Hasil Belajar. Indonesian Journal of Science and Mathematics Education, 2(3), 372-379. https://doi.org/10.24042/ijsme.v2i3.4363

De Porter, et al. (2017). Quantum Teaching Mempraktikkan Quantum learning di Ruang-ruang Kelas. Mizan Pustaka.

Depdiknas. (2007). Rencana strategis Departement Pendidikan Nasional 2005 - 2009. Pusat Informasi dan Humas Departemen Pendidikan Nasional.

Djaali. (2012). Psikologi Pendidikan. PT Bumi Angkasa.

Geel, M. V. (2015). Assessing The Effects Of A School Wide Data Based Decision Making Intervention On Student Achievement Growth In Primary Schools. American Educational Research Journal, 35, 135.

Gentry, R. (2013). Collaboration Skills Pre-Service Teachers Acquire In A Responsive Preparation Program. Journal of Instructional Pedagogies, 1-9.

Gunawan, M. dan. (2012). Pendidikan IPS Filosofi, konsep, dan Aplikasi. Alfabeta.

Hamalik, O. (2012). Proses Belajar Mengajar. Bumi Aksara.

Jaynes, R. J. W. dan J. H. (2016). Motivasi Belajar. Cerdas Pustaka.

Khairani, Annisa Laras, D. (2016). Pengaruh Model Pembelajaran Quantum Teaching Tipe Tandur Diintegrasikan Dengan Kartu Tangram Terhadap Hasil Belajar Matematika Siswa. Jurnal Pendidikan Matematika \& Matematika., 2(1).

Kirom, A. (2017). Peran Guru Dan Peserta Didik Dalam Proses Pembelajaran Berbasis Multikultural. Al Murabbi, 3(1), 69-80. 
Lestari, P. \& A. H. (2018). Penerapan Model Quantum Teaching Sebagai Upaya Meningkatkan Hasil Belajar Siswa Pada Mata Pelajaran IPS Kelas VIII Smp Pgri 3 Jakarta. Research and Development Journal Of Education, 5(1).

Lott, J., \& Kenny, L. W. (2013). State Teacher Union Strength And Student Achievement. Economics Of Education Review, 35, 93-103.

Mulyati, T. (2016). Pendekatan Konstruktivisme Dan Dampaknnya Bagi Hasil Belajar Matematika Siswa SD. EduHumaniora / Jurnal Pendidikan Dasar Kampus Cibiru, 1(2). https://doi.org/10.17509/eh.v1i2.2738

Musyafa, H. (2015). Sang Guru: Novel Biografi Ki Hadjar Dewantara, Kehidupan, Pemikiran, dan Perjuangan Pendiri Tamansiswa (1889-1959). Mizan Media Utama.

Najib, D. A. (2016). Pengaruh Penerapan Pembelajaran Bermakna (Meaningfull Learning) Pada Pembelajaran Tematik IPS Terpadu Terhadap Hasil Belajar Siswa Kelas III di MI Ahliyah IV Palembang. Jurnal Imiah PGMI. Jurnal.radenfatah.ac.id

Riyanto, Y. (2012). Paradigma Baru Pembelajaran sebagai Referensi bagi Guru Pendidik dalam Implementasi Pembelajaran yang Efektif dan Berkualitas. Kencana Prenada Media Group.

Sardiman. (2017). Interaksi dan Motivasi Belajar Mengajar. Rajawali Pers.

Sarwi. (2013). Implementasi Model Pembelajaran Inovatif untukMengembangkan Nilai Karakter Siswa SMP. Jurnal Penelitian Pendidikan.

Zakirman, Z. Z. (2017). Pengelompokkan Gaya Belajar Mahaanak Menurut Teori Honey Mumford Berdasarkan Intensitas Kunjungan Pustaka. RISTEKDIK: Jurnal Bimbingan Dan Konseling, 2(2). 